\title{
Proses Komunikasi Organisasi di dalam Biro Iklan di Ada Indonesia dan Ada Singapura
}

\author{
Claudia Harlim, Gregorius Genep Sukendro \\ geneps@fikom.untar.ac.id, geneps@fikom.untar.ac.id \\ Fakultas Ilmu Komunikasi Universitas Tarumanagara
}

\begin{abstract}
This research is studying the process of organization communication in an advertising agency at ADA Indonesia and ADA Singapore. This research is done using a qualitative descriptive approach with ethnography method. The data that has been used was prim and secondary data. Prim's data was one that contains interviews with the resource of information. Hence secondary data was one that contains data that resource from books and other resources. The Theories that have been used were Organizational theory, Organizational Culture theory, Climate of Organization, and Organization Communication. To gather the data, interviews, observation, bibliography study and online searching technique was used. The outcome from this research shows that the communication process that was used now is right and comfortable to apply on company's daily organizational life. It also shows that even though the company is organizational, it didn't imply any seniority concept or cultures that could corrupt the communication flow that has been functioning up until now on the company.
\end{abstract}

Keywords: communication process, culture, Organization, organizational communication.

\begin{abstract}
Abstrak
Penelitian ini membahas mengenai proses komunikasi organisasi di dalam biro iklan di ADA Indonesia dan ADA Singapura. Penelitian ini dilakukan dengan menggunakan pendekatan penelitian deskriptif kualitatif dengan metode penelitian etnografi. Data yang digunakan dalam penelitian ini terdiri dari data primer dan sekunder. Data primer berupa hasil wawancara penulis dengan para narasumber, sedangkan data sekunder berupa data yang diperoleh dari buku dan sumber lain. Teori yang digunakan terdiri dari organisasi, budaya organisasi, iklim organisasi, dan komunikasi organisasi. Teknik pengumpulan data yang digunakan yaitu wawancara, observasi, studi kepustakaan dan penelusuran data online. Hasil dari penelitian ini menunjukkan bahwa proses komunikasi yang berjalan sekarang dinilai tepat dan nyaman untuk dijalankan. Bahwa walaupun perusahaan bersifat organisasional tetapi tidak memiliki kesenioritasan maupun budaya yang dapat mengacaukan komunikasi di dalam organisasi perusahaan tersebut.
\end{abstract}

Kata Kunci: budaya, komunikasi organisasi, organisasi, proses komunikasi.

\section{Pendahuluan}

Komunikasi merupakan aktivitas paling mendasar manusia yang tidak akan pernah lepas dari keseharian antar sesama makhluk hidup. Dengan berkomunikasi manusia saling terhubung antara satu sama lain, dapat saling mengerti dan bekerjasama dengan baik dalam kesehariannya di lingkungan kerja, keluarga maupun pergaulan. Komunikasi mempunyai peranan penting yaitu sarana interaksi antar individu sebagai suatu proses sosial yang sangat mendasar dalam kehidupan manusia. Konteks 
komunikasi memiliki ciri dan karakteristik yang berbeda dengan konteks komunikasi lain, khususnya dalam komunikasi organisasi.

Pada komunikasi organisasi, biasanya proses komunikasinya lebih terorganisir dan teratur. Dengan demikian, komunikasi menjadi salah satu aspek penting dalam kehidupan berorganisasi agar dapat terciptanya komunikasi organisasi yang baik. komunikasi yang baik dan tepat merupakan salah satu kunci sukses untuk menjadikan suatu organisasi menjadi lebih maju dan berkembang. Hal tersebut dapat terjadi dikarenakan informasi merupakan kebutuhan dasar dan penting sebagai acuan meraih organisasi yang lebih maju.

Begitu pula dengan PT. ADA Indonesia. PT. ADA Indonesia merupakan suatu biro iklan digital startup yang bergerak dalam bidang periklanan digital dengan sosial media dan media SMS sebagai landasan dalam beroperasi. PT. ADA Indonesia merupakan sister company dari Axiata Group yang berpusat di Kuala Lumpur, Malaysia. ADA merupakan biro iklan digital yang memanfaatkan data dalam beriklan. Data yang dipunyai merupakan jaringan data terluas dan terbesar di Asia Selatan dan Asia Tenggara. Dengan adanya keuntungan dari jaringan data tersebut, ADA selalu berusaha untuk membantu konsumen untuk beriklan dengan efektif dan efisien, ADA Indonesia juga memiliki etos kerja yang bagus dikarenakan komunikasi antar karyawan, karyawan-manager, manager-country director, country director-CEO yang sangat baik.

Oleh sebab itu di PT. ADA Indonesia, agar terjalinnya komunikasi yang baik serta terjaganya komunikasi yang nantinya dapat berbuah loyalitas terhadap organisasi, PT. ADA Indonesia selalu melakukan "Friday Fun Time". Sebuah kegiatan yang dilakukan agar semua karyawan dan pimpinan perusahaan dapat berkumpul bersama diluar jam kantor dan bergaul layaknya teman biasa agar tidak terciptanya kecanggungan antara pegawai dan pimpinan.

Selain itu juga ada agenda "Wednesday Lunch", sebuah agenda yang dilakukan setiap hari minggunya pada hari rabu, dimana semua pegawai akan mendapatkan makan siang gratis yang difasilitasi oleh perusahaan. Perusahaan juga memfasilitasi para pegawai dengan kulkas yang berisikan berbagai macam camilan, minuman serta buah-buahan yang dapat dinikmati kapanpun dan oleh siapa saja. Biasanya HRD akan melakukan belanja bulanan untuk menyetok barang-barang tersebut. Tak hanya itu, perusahaan juga menyediakan fasilitas "Relax Zone" yang diharapkan dapat membantu para pegawai untuk beristirahat sejenak dan membuang stress, yang berupa game console, darts dan meja Football yang dapat digunakan semua orang.

Seperti yang dikutip dari Jurnal Komunikasi oleh Gregorius Genep Sukendro (2019), Beliau mengungkapkan bahwa banyak perusahaan maupun Lembaga memanfaatkan media digital sebagai bentuk komunikasi dengan para konsumen. Ternyata ditemukan kesamaan antara pendapat Bapak Gregorius Genep Sukendro dengan penelitian yang sedang penulis lakukan. Bahwa ternyata setelah melakukan proses wawancara dan observasi, penulis melihat bahwa ADA Indonesia \& ADA Singapura juga menggunakan media digital sebagai bentuk komunikasi terhadap konsumen, begitu pula para klien yang bekerja sama dengan ADA Indonesia \& ADA Singapura terhadap konsumen mereka.

\section{Metode Penelitian}

Penelitian ini adalah penelitian yang bersifat kualitatif. Penelitian yang digunakan yaitu penelitian kualitatif deskriptif. Penelitian kualitatif deskriptif adalah 
berupa penelitian dengan metode atau pendekatan etnografi (ethnography). Istilah etnografi sendiri berasal dari kata ethno (bangsa) dan graphy (menguraikan), jadi etnografi yang dimaksud adalah usaha untuk menguraikan kebudayaan atau aspekaspek kebudayaan (Moleong, 1990).

Etnografi komunikasi secara sederhananya adalah pengkajian peranan Bahasa dalam perilaku komunikasi suatu masyarakat, yaitu cara-cara bagaimana Bahasa dipergunakan dalam masyarakat yang berbeda-beda kebudayaannya (Koentjaraningrat, dalam Kuswarno, 2008). Dari pernyataan tersebut dapat disimpulkan bahwa etnografi adalah upaya untuk mendefinisikan suatu aspek-aspek dan makna sebuah budaya.

Menurut Sugiyono (Sugiyono, 2011), Teknik pengumpulan data merupakan langkah yang paling pertama dalam penelitian dikarenakan tujuan utama dari penelitian yakni mendapatkan data. Pencatatan sumber data melalui wawancara atau pengamatan merupakan hasil gabungan dari kegiatan melihat, mendengar, dan bertanya. Berbagai sumber data yang akan dimanfaatkan dalam penelitian ini sebagai berikut.

Sumber data primer yang digunakan dalam penelitian ini adalah hasil wawancara dengan 3 orang narasumber dari ADA Indonesia dan 2 orang narasumber dari ADA Singapura. Sedangkan sumber data sekunder dari penelitian ini adalah sumber tertulis seperti sumber buku, majalah ilmiah, sumber berita online dan dokumen-dokumen dari pihak yang terkait yaitu ADA Indonesia dan ADA Singapura.Penulis melakukan wawancara dengan HRD dari ADA Indonesia, Head of Strategy \& Performance, Manager of Digital Planning \& Strategy, Senior Manager Product Innovation dan Data Intelligence dan Senior Manager of Digital Planning \& Strategy mengenai proses komunikasi organisasi serta budaya organisasi yang ada di ADA Indonesia dan ADA Singapura.

\section{Hasil Temuan dan Diskusi}

Penulis melakukan wawancara dengan HRD dari ADA Indonesia, Head of Strategy \& Performance, Manager of Digital Planning \& Strategy, Senior Manager Product Innovation dan Data Intelligence dan Senior Manager of Digital Planning \& Strategy mengenai proses komunikasi organisasi serta budaya organisasi yang ada di ADA Indonesia dan ADA Singapura.

Berdasarkan hasil data yang telah penulis rampungkan, maka dapat disimpulkan bahwa program-program yang dijalankan perusahaan berdampak positif terhadap karyawan, baik itu secara profesionalitas maupun secara mental. Dimaksudkan dalam pernyataan ini bahwa didukung dengan hasil wawancara penulis dengan para narasumber, program perusahaan yang diberikan memberi dampak bagi para karyawan. Dimana dampak tersebut merupakan dampak positif yang dirasakan. Secara singkat, dampak yang dirasakan berupa keterbukaan diri dan kehidupan sosial di kantor yang lebih baik dari yang sebelumnya. Juga merasa bahwa mereka memiliki perluasan hubungan professional dengan klien lain melalui sambungan karyawan lainnya.

Juga terbukti bahwa budaya dari masing-masing negara tidak menjadi penghalang bagi karyawan antar negara untuk berkomunikasi dengan satu sama lain. Khususnya ADA Indonesia dan ADA Singapura, kedua perusahaan ini memiliki hubungan yang lebih dekat dibanding dengan perusahaan lainnya karena ketidaklengkapan seluruh tim di ADA Singapura. ADA Singapura masih bergantung 
kepada ADA Indonesia dalam hal eksekusi iklan. Oleh karena itu, pastinya akan terjadi banyak komunikasi antar karyawan ADA Indonesia dan ADA Singapura. Namun nyatanya selama ini, tidak pernah terjadi kesalahpahaman ataupun perselisihan yang disebabkan oleh aspek budaya.

Analisis komunikasi internal organisasi yang terbentuk antara anggota organisasi juga merupakan salah satu hasil temuan dari penelitian ini. Menurut arus aliran informasi dalam proses komunikasi, dapat diidentifikasi bahwa ada beberapa pola arus komunikasi di dalam suatu organisasi. Arus-arus ini juga yang ditemukan serta diterapkan oleh PT. ADA Asia Indonesia, yakni:

a. Komunikasi Vertikal

Komunikasi vertikal terjadi di antara orang-orang yang berposisi secara hierarkis dan dapat berupa arus komunikasi ke bawah maupun ke atas. Komunikasi ke bawah kerap kali lebih menonjol daripada komunikasi ke atas dalam kehidupan sehari-hari. Terbagi menjadi 2 yaitu:

1) Komunikasi ke Bawah,

Adalah penyampaian informasi dari atasan kepada bawahan atau dari pimpinan kepada staf. Komunikasi ke bawah mengalir menurut jenjang hierarkis dari wewenang yang lebih tinggi kepada wewenang yang lebih rendah dari tingkatan manajemen. Komunikasi ke bawah bertujuan untuk menyediakan informasi yang membantu para karyawan mengerjakan pekerjaan, mengendalikan dan pengawasan kerja.

2) Komunikasi ke Atas

Adalah rangkaian kegiatan penyampaian informasi dari pejabat yang mempunyai kedudukan lebih rendah kepada pejabat yang berkedudukan lebih tinggi, layaknya dari staf ke pimpinan. Wayne Pace dan Don F. Faules yang memberikan alasan mengapa arus komunikasi ini sulit dilaksanakan dalam prakteknya. Hal-hal tersebut yakni kecenderungan bagi pegawai untuk menyembunyikan pikiran mereka, perasaan bahwa pimpinan organisasi tidak tertarik terhadap masalah pegawai, kurangnya penghargaan bagi arus komunikasi ke atas yang dilakukan pegawai, serta perasaan bahwa pimpinan tidak dapat dihubungi dan tidak tanggap pada apa yang disampaikan pegawai.

b. Komunikasi Horizontal

Arus komunikasi horizontal atau yang dikenal dengan komunikasi ke samping adalah proses penyampaian informasi yang melibatkan pegawai atau pemimpin yang masing-masing mempunyai level hierarki jabatan yang sejajar.

Dan pula PT. ADA Asia Indonesia sangat puas dengan hierarki yang ada. Dimana menurut hasil wawancara penulis dengan HRD ADA Indonesia, beliau mengatakan bahwa ADA sekarang sangat puas akan hierarki yang ada dan hal tersebut dinilai sebagai hal yang tepat serta efektif karena hierarkis yang ada tidak bersifat kompleks mengingat ADA secara keseluruhan masih termasuk sebagai perusahaan startup.

\section{Simpulan}

Maka dari hasil penelitian yang penulis lakukan, dapat disimpulkan bahwa para karyawan merasa puas dan menerima dampak positif dari program-program yang dijalankan perusahaan. Program tersebut berupa Wednesday Free Lunch serta Friday 
Fun Time. Para karyawan juga merasa ADA sebagai perusahaan serta organisasi adalah institusi yang dapat membantu individu untuk berkembang menjadi lebih baik dan dapat menopang individu untuk belajar lebih jauh lagi tentang hal yang berhubungan dengan pekerjaan mereka di perusahaan tersebut maupun akan hal-hal yang berada diluar ranah pekerjaan.

Para karyawan juga merasa ADA sebagai perusahaan adalah tempat yang sangat cocok bagi mereka karena menurut mereka adalah sebuah perusahaan yang berbeda dari perusahaan lainnya. Mau dari program sampai nilai yang dipegang teguh perusahaan pun berbeda dari perusahaan lain dan mereka puas akan hal tersebut. Dimana mereka merasa bahwa teman-teman sekantor mereka lebih seperti keluarga dibanding teman sekantor. Juga aspek dimana kesenioritasan tidaklah banyak berarti diperusahaan tersebut. Jabatan hanya diberlakukan ketika adanya sebuah penilaian ataupun pelaporan terhadap pekerjaan, namun dalam kehidupan sehari-hari mereka merasa bahwa hal tersebut tidak diberlakukan. Karena mereka bebas untuk berkomunikasi dengan siapa saja bahkan langsung kepada CEO perusahaan mereka sendiri.

\section{Ucapan Terima Kasih}

Ucapan terima kasih yang penulis berikan kepada para narasumber untuk meluangkan waktunya dan memberi informasi kepada penulis selama proses pengumpulan data untuk penelitian ini. Penulis juga mengucapkan terima kasih yang sebesar-besarnya kepada Dosen Pembimbing, teman-teman, serta Fakultas Ilmu Komunikasi Universitas Tarumanagara.

\section{Daftar Pustaka}

Gregorius, Genep Sukendro., \& Pandrianto, Nigar. (2019). Diagnosa Komunikasi Brand Activation Dan Media Digital Atas Eksistensi Brand Studio Rekaman Lokananta. Jurnal Komunikasi, Vol. 11, No. 2, Desember 2019.

Kuswarno, Engkus. (2008). Etnografi Komunikasi. Bandung: PT. Widyapadjaran. Moleong, Lexy J. (1990). Metodologi Penelitian Kualitatif. Jakarta: Remaja Karya. Pace, R. Wayne \& Faules, Don F. (2010). Komunikasi Organisasi. Bandung: PT. Remaja Rosdakarya.

Sugiyono. (2011). Metode Penelitian Pendidikan. Bandung: Alfabeta. 